\title{
Calling European Union Treaty Referendums: Electoral and Institutional Politics
}

DOI:

10.1111/1467-9248.12176

Document Version

Accepted author manuscript

Link to publication record in Manchester Research Explorer

\section{Citation for published version (APA):}

Prosser, C. (2016). Calling European Union Treaty Referendums: Electoral and Institutional Politics. Political Studies, 64(1), 182-199. https://doi.org/10.1111/1467-9248.12176

\section{Published in:}

Political Studies

\section{Citing this paper}

Please note that where the full-text provided on Manchester Research Explorer is the Author Accepted Manuscript or Proof version this may differ from the final Published version. If citing, it is advised that you check and use the publisher's definitive version.

\section{General rights}

Copyright and moral rights for the publications made accessible in the Research Explorer are retained by the authors and/or other copyright owners and it is a condition of accessing publications that users recognise and abide by the legal requirements associated with these rights.

\section{Takedown policy}

If you believe that this document breaches copyright please refer to the University of Manchester's Takedown Procedures [http://man.ac.uk/04Y6Bo] or contact uml.scholarlycommunications@manchester.ac.uk providing relevant details, so we can investigate your claim.

\section{OPEN ACCESS}




\title{
Calling European Union treaty referendums
}

\section{Electoral and institutional politics}

\author{
Christopher Prosser \\ University of Manchester ${ }^{1}$ \\ chris.prosser@manchester.ac.uk \\ Political Studies, 64 (1), pp. 182-199, 2016.
}

\begin{abstract}
Many European integration treaties, most notably the failed Constitutional Treaty have faced ratification by referendum in various member states. Although the literature on voting behaviour in these referendums in now well established, the reasons why these referendums were held in the first place is under scrutinised. This article examines the reasons EU member-states decide to call referendums in order to ratify EU treaties and argues that they do so primarily as a result of domestic political pressure arising from three sources: electoral pressure when the EU is unpopular and elections are close, rules governing the use of referendums, and domestic institutional veto players. This theory is tested using a combination of single and multi-level logistic regression analysis which finds support for the hypotheses developed here.
\end{abstract}

\footnotetext{
${ }^{1}$ At the time of acceptance, St Catherine's College, Oxford
} 
Several times in the history of European integration the implementation of a new treaty has been delayed or stopped entirely because it has been rejected in a referendum. The Danish electorate voted no to the Maastricht Treaty, and Irish voters rejected the Nice and the Lisbon treaties. The most remarkable example of the role that referendums have played in European integration was the failed Treaty establishing a Constitution for Europe (the Constitutional Treaty): ten European Union (EU) member-states announced that they would hold referendums to ratify the treaty. ${ }^{2}$ On May 29 and June 1, 2005 the Constitutional Treaty was rejected by French and Dutch voters, and the treaty was derailed.

Of the 13 times a treaty has been put to referendum, it has been (at least initially) rejected on five occasions. Much scholarly work has gone into trying to understand voter behaviour at European integration referendums (Franklin, Marsh, and McLaren, 1994; Garry, Marsh, and Sinnott, 2005; Glencross and Trechsel, 2011; Hobolt, Spoon, and Tilley, 2009; Hobolt, 2005, 2006a, 2007). We know comparatively little however, about why those referendums were held in the first place. In setting out an agenda for future referendum research Hobolt argued that "more research is... needed to establish when and why governments opt for the referendum strategy, despite the obvious risks" (2006b, p. 158). This article attempts to answer this question and argues that the decision to hold a referendum on a European integration treaty is primarily driven by the combination of low public support for European integration and the timing of upcoming elections, and the configuration of domestic political institutions.

\section{An Under Studied Question}

Although there is a well-established literature on many aspects of referendums more generally from the reasons governments choose to hold them (Bjørklund, 1982; Butler and Ranney, 1978,

\footnotetext{
${ }^{2} \mathrm{EU}$ is used as a shorthand to denote both the European Union and its predecessor organisations.
} 
1994; Morel, 2001), to citizen attitudes to referendums and direct democracy (Bowler, Donovan, and Karp, 2007; Hibbing and Theiss-Morse, 2002), and the desirability of referendums as political instruments (Elster, 1998; LeDuc, 2003; Qvortrup, 2005) - with the obvious exception of the study of voting behaviour, the literature on EU referendums more specifically is fairly small. The earliest approach to understanding the decision to hold EU treaty referendums looked at them from the perspective of being a bargaining tool in negotiations at Intergovernmental Conferences (Hug and König, 2002; Schneider and Cederman, 1994). These scholars argued that European integration is a two-level game and that member-states may tie their hands on the domestic level, by announcing a referendum, in order to increase their bargaining strength at the European level. Closa (2007) also suggests another possible European level influence on the decision to hold a referendum is the ratification process in other member-states, arguing that debates and policy decisions surrounding treaty ratification in one member-states influence debates in other member-states and so the decision to hold a referendum by one member state will increase the pressure on others to do the same.

It was not until the flurry of referendums surrounding the Constitutional Treaty that a few scholars began to turn their attention towards the role that domestic political factors might play on the decision to hold a referendum on an EU treaty. Drawing on the more general literature on the reasons referendums are held Mateo (2006) argues that most of the Constitutional Treaty referendums were driven by domestic political factors. Similarly, Closa (2007) finds that the absence of solid parliamentary majorities, disputes within ruling parties, and electoral calculation drove the decision to hold referendums on the Constitutional Treaty. Finke and König (2009) contend that Constitutional Treaty referendum decisions were driven by the desire of treaty-friendly governments to circumvent parliamentary opposition, also noting that governments sought to decouple the referendum issue from electoral campaigns. Finally, Dür and Mateo (2011) use measures of government and opposition party positions on whether to hold a referendum, public support for the 
treaty, party size, and the time until the next election to argue that electoral competition was a primary driver behind party positions on referendums.

Moving beyond the Constitutional Treaty case, Oppermann (2013a) explores the relationship between domestic and European level motivations for holding referendums and develops a two-bytwo (European/domestic and offensive/defensive) typology. Applying this typology to all discretionary EU referendums Oppermann concludes that although referendums fitting each type have been held, the single most common type of referendum is one that was held for domesticdefensive reasons. Additionally, Qvortrup (2014), drawing on the earlier work of Bjørklund (1982) and Morel (2001), examines the cases where referendums have been held on EU issues to argue that referendums on European integration are held for tactical reasons, driven by the desire to increase electoral support.

With the exception of Oppermann (2013a) and Qvortrup (2014), the existing literature on the domestic politics of EU referendums has focused on the Constitutional Treaty. Given that the Constitutional Treaty is an atypical case in both the number of referendums held on it and the politicisation of debates surrounding it, it is not clear whether we can draw generalizable conclusions about EU referendums from the Constitutional Treaty or if these arguments only fit the specific case. This article attempts to answer this question by examining the ratification of all major EU treaties.

Although the literature on the domestic factors which influence the decision to hold EU treaty referendums is small, there is an emerging consensus that the referendums on the Constitutional Treaty were driven by electoral politics. The argument put forward here follows this literature and argues that the primary driver of referendums has been domestic political pressure. This pressure can be divided into two forms - electoral pressure and institutional pressure. Electoral pressure to hold a referendum stems from the desire for governments to avoid being punished by voters for an unpopular policy. By holding a referendum governments seek to depoliticise the issue of European 
integration at elections and avoid voter defections to more Eurosceptic parties. Institutional pressures stem from potential veto players to the ratification of the treaty (such as an executive president or the upper chamber in a bicameral parliament) and the use of referendums to bypass such veto players.

These two factors should be viewed as complementary rather than competing explanations. When elections are near and a government's European policy is unpopular, the bargaining power of veto players will increase and they will have a greater effect on government decisions. Similarly, when veto players have more of a role in ratifying a treaty the potential for political conflict is higher, increasing the salience of European issues, which may in turn increase electoral pressure.

This argument fits squarely with Oppermann's (2013a) domestic-defensive type. It does not aim to deny the possibility of domestic-offensive or European level motivations in the decision to hold a referendum on a European treaty. However, driven by the desire for parsimony and the limitations of a relatively small dataset, these issues are put to one side for the time being.

\section{Electoral Pressure}

EU treaty ratification is a difficult issue for governments to deal with at an electoral level because, unlike other political issues, governments cannot strategically modify the content of a treaty for electoral reasons once it has been signed. As they are negotiated at an intergovernmental level, once a treaty is signed the space for strategic manoeuvring is very limited. When treaty ratification is on the political agenda, governments are restricted in their policy manoeuvring to a binary choice whether they are pro or anti ratification. Faced with this policy bind one of the few strategic choices available to governments facing electoral punishment from an electorate hostile to European integration is whether to try to depoliticise the issue by holding a referendum. By allowing voters a ballot specifically on European integration, governments hope that European issues will not affect 
vote choice at subsequent elections. Of course, governments do not face electoral pressure evenly throughout their terms in office, particularly in the case of generally low salience issues such as European integration and so governments will face greater electoral pressure when they have to ratify a treaty closer to an election, suggesting an interaction between public support for European integration and the time until the next election.

Hypothesis 1a: Referendums are more likely to be held to ratify a treaty when public support for European integration is low.

Hypothesis $1 b$ : Referendums are more likely to be held to ratify a treaty when elections are close.

Hypothesis 1c: There will be an interaction between public support for European integration and the time until the next election, such that referendums are more likely to be held when public support for integration is low and elections are close.

\section{Legal obligations}

One of the most obvious drivers of holding a referendum is some form of legal requirement to do so, as found in Ireland and Denmark. However the fact that Denmark did not hold referendums on the Nice and Lisbon treaties is the first indication that referendums are not simply a matter of legal determinism. The provisions governing the requirement of referendums are found in Section 20 of the Danish Constitution, which states:

'Powers ... may... be transferred to international authorities... A majority of fivesixths of the Members of Parliament is required to pass Bills in this respect. If such a majority is not obtained... it is submitted ... for approval or rejection in accordance with the rules established for referendums...' 
As it is possible to ratify treaties by supermajority a referendum is never absolutely necessary, however no treaty has been ratified this way. Section 20 applies when powers are transferred to international authorities. When Section 20 does not apply, as it was deemed to be the case for the Nice and Lisbon treaties, ratification falls under Section 19, which covers other aspects of foreign policy and only requires a Bill to pass a normal majority vote. Although whether a treaty falls under Section 19 or 20 should technically be a legal matter, as Laursen (2010) argues, in reality there is a great deal of political involvement in the decision.

Although Ireland has held referendums to ratify every treaty since the Single European Act (SEA), there is also ambiguity in whether a referendum is always legally obligatory. The requirement to hold referendums arose from a legal decision in Crotty v. An Taoiseach, which was brought to challenge the Irish government's ratification of the SEA. Ireland's entry to the EC was ratified by the third amendment to the Irish constitution which states that:

'No provision of this Constitution invalidates laws ... adopted by the State necessitated by the obligations of membership of the Communities or prevents laws ... adopted by the Communities... from having the force of law...'

This allows the government the power to introduce some European laws into Irish law without further amending the constitution. The Crotty case decided that the provisions of the SEA relating to foreign policy cooperation did not meet the requirement of an 'obligation of membership' and ruled that the government could not enter foreign policy cooperation without a further change to the constitution, which in turn required a referendum. Consequently the SEA was put to a referendum, and so has every EU treaty since, though it is far from clear that they have been legally necessary under the reasoning of the Crotty case.

With the exception of the Irish referendum on the SEA it is not simply a matter of referendums being held because there is a legal requirement to do so. Rather, legal arrangements make the 
political pressure to hold a referendum much greater because they increase the political costs of parliamentary ratification.

Hypothesis 2: Referendums are more likely to be held when a country has a legal requirement for a referendum on some EU treaties, even if the legal requirement does not explicitly extend to the treaty in question. ${ }^{3}$

\section{Institutions and Veto Players}

As veto players in the political process, political institutions are also expected to influence the decision to hold a referendum. Tsebelis (2002) defines a veto player as an actor whose consent is required to change the status quo. Although a referendum could be considered as a veto player in its own right this article draws on the idea that referendums can be used as a means of bypassing institutional obstacles to policy change (Uleri, 2002).

According to the logic of the veto players model, when players have different preferences on a policy spectrum, policy will shift to a Pareto optimal point between their different preferences. However, when the policy in question is a binary choice (as it is in the case of treaty ratification), if any player

\footnotetext{
${ }^{3}$ It could also be true that the opposite case - a legal provision preventing a referendum being held to ratify international treaties, such as exists in Italy - might also apply. Since Italy has never held a referendum on an EU treaty this argument could be correct, but because there is no variation of outcome, it is impossible to test statistically. The fact that there have been frequent political demands in Italy for treaty referendums and the fact that a referendum was held on the powers of the European Parliament in 1989 suggests that the absence of treaty referendums is not simply a case of legal determinism - were there sufficient political will for a referendum a way would be found to hold one. If the reader is unconvinced they should be assured that the results presented here are robust to the exclusion of Italy.
} 
has different preferences, a compromise position is impossible as a point between the choices does not exist. Consequently, if veto players have different preferences on ratification this may result in policy deadlock. If this situation arises (or is anticipated) then governments may resort to referendums as a tool to bypass veto players or as a bargaining tool to win their support.

In many cases it is impossible to know the preferences of different actors with regard to treaty ratification and so rather than a preference modelling approach this article takes a probabilistic view on the impact of veto players that is agnostic as to the actual preferences of different actors and simply argues that because they must exist in order to present an obstacle to policy the probability of referendums is higher in countries where veto players are present. In particular two key institutions are expected to increase the likelihood of a referendum: an executive president and a bicameral legislature.

Hypothesis 3a: The presence of a bicameral legislature will increase the likelihood of a referendum being held.

Hypothesis 3b: The presence of an executive President will increase the likelihood of a referendum being held.

The literature on referendums suggests that they are also used to bypass opposition from unicameral parliaments and the lower chamber of bicameral parliaments in cases where the government does not have a legislative majority (Bjørklund, 1982; Morel, 2001). Closa (2007) argues that this is true in the cases of EU treaty ratification as well, and so this theory will be examined alongside the other institutional hypotheses.

Hypothesis 3c: The absence of a parliamentary majority will increase the likelihood of a referendum being held. 


\section{Treaty level effects}

The asymmetric distribution of referendums between different treaties suggests that the drive to hold ratification referendums may not be completely attributable to domestic political concerns. Several treaty level factors might influence the decision to hold a referendum: First, the degree of change a treaty brings might affect the electoral pressure a government will face when ratifying the treaty as citizens are concerned with new developments in European integration. It is probably no coincidence that the two treaties that have had the most referendums held on them, Maastricht and the Constitutional Treaty, are also two of the most important treaties in the history of European integration in terms of structural and symbolic changes. Secondly, member-states holding referendums may add pressure on other member-states to do the same, such as Closa (2007) suggests occurred with the Constitutional Treaty. Conversely it may be in their collective interest to avoid referendums so as not to risk ratification failure. In the case of the Lisbon treaty Oppermann (2013b) suggests that this helps explain why member-states avoided referendums despite public pressure to hold them.

The research design adopted here is intended to explore the domestic drivers of the decision to hold a referendum and so is not well suited to disentangling these possible treaty level effects, a question which is better suited to other methods such as process tracing. It can however offer an exploratory analysis of treaty level effects which will reveal whether any discernable treaty level effects exist or whether the pattern of referendums across treaties is simply due to the confluence of other factors at particular treaties. If such treaty level effects do exist, the results here can point future research towards the treaties where, holding domestic political concerns constant, the number of referendums held was greater or fewer than we would otherwise expect. 


\section{Data and Methodology}

As the unit of analysis is the government of an EU member-state this article analyses aggregate country level data using a combination of logistic regression with clustered standard errors and multi-level mixed effect logistic regression to determine the effect that the hypothesised variables have on the probability of a country holding a referendum. The cases $(n=106)$ are each time a country needed to ratify a treaty, beginning with the SEA and including all treaties up to and including the Lisbon Treaty. ${ }^{4}$

The dependent variable is a binary measure of whether or not a referendum was called to ratify a treaty (one $=$ referendum). In 19 of the 106 times a treaty faced ratification a referendum was called, a list of which is shown in table 1.

Data on public opinion towards European integration is taken from the Eurobarometer survey series, using the closest survey that was conducted before each treaty. Aggregate level public support for European integration is measured by the public support variable which is the proportion of respondents in each country answering 'a good thing' to a question that asks survey respondents whether they "think [their country's] membership of the European Union is a good thing/bad thing/neither a good or bad thing?"

The amount of time until the next election, days till election, is calculated by counting the number of days between the signing date of the treaty and the closest election following the signing of the

\footnotetext{
${ }^{4}$ This does not include the ratification of entry or founding treaties. While the ratification of reform treaties can be considered generally equivalent there are good reasons why the other treaties should not. Joining the EU is a very different process to ratifying a treaty when already a member and the political pressures will be different in each case.
} 
treaty. ${ }^{5}$ Details on when elections are held come from Mackie and Rose (1990) prior to 1991 and from the European Journal of Political Research data yearbooks from 1991 onwards. Where elections are held on multiple days the date of the first day of the election was used.

\begin{tabular}{cc}
\hline Treaty & Countries ratifying treaty by referendum \\
\hline SEA & Denmark \\
Ireland & Denmark \\
Maastricht & France \\
& Ireland \\
\hline Amsterdam & Denmark \\
& Ireland \\
\hline Nice & Ireland \\
& Czech Republic* \\
& Denmark* \\
& France \\
& Ireland* \\
& Luxembourg \\
Constitution & Netherlands \\
& Poland* \\
& Portugal* \\
& Spain \\
& United Kingdom* \\
\hline Lisbon & Ireland \\
\hline Referendums held to ratify EU Treaties. &
\end{tabular}

\footnotetext{
${ }^{5}$ It might be objected that the days to election might be misleading in cases where an early election was called and a better measure would be the length of current government incumbency. The same objection might be made here - it assumes early elections catch governments by surprise. The statistical analysis was run with both measures and the results are robust to the use of either. Days till Election is used because interpretation of the coefficients is more intuitive given the argument that referendums are more likely when elections are close.
} 
A country's institutional arrangements are measured by a series of binary variables, which are coded one when the institution is present. Whether or not a country has some legal obligation to hold a referendum is measured by compulsory referendum. Information on whether a country has a unicameral or bicameral parliament is measured by bicameral and is taken from the International Parliamentary Union's Parline database. Semi-presidential, which measures whether a country has an executive president is taken from Shugart (2006). Data on whether a government did not have a parliamentary majority at the time of a treaty is measured by minority and is taken from the European Journal of Political Research data yearbooks and Woldendorp, Keman and Budge (2000). Summary statistics and the coding of each of the binary variables are shown in table A1 in the appendix.

Although logistic regression is a common statistical tool in political science, the relatively small dataset here presents a number of challenges. First, the data is structured with cases cross-classified at the country and treaty levels. The ideal approach to this situation would be to conduct a multilevel model with cross-classified random effects. From a practical standpoint this approach is impossible as the small sample size causes insurmountable estimation problems because of the small sample size and the models fail to converge. Further analysis suggests that this is less of a problem than it might first appear. Conducting likelihood ratio tests on the models alternatively specified with treaty and country level random effects suggests that although including treaty level effects results in a model superior to a single-level model the same is not true for the country level model, which suggests that the variables included in the fixed effects component of the model sufficiently account for the variance due to country differences.

From a theoretical standpoint however there are reasons to be cautious about using multilevel models with a small number of higher level units. The number of treaty level units falls well below the minimum number of units recommended by Stegmueller (2013) and so there is a danger that 
the results of these models may be biased. As the dataset includes all of the relevant EU treaties, gathering more data is impossible.

The solution to this problem is to adopt a two stage approach and to confirm the overall robustness of the analysis by the convergent validity of the results of each stage. The first stage of the analysis is conducted using single level logistic regression without treaty level effects. The second stage then adds treaty level effects to the single level model in two ways, first by including treaty fixed effects in the single model (to avoid estimation problems each treaty is added to the model separately) and then by replicating the single level model as a multilevel model with cases grouped at the treaty level.

An additional statistical concern is that we might expect the error terms to suffer from heteroskedasticity because of two factors affecting the data - referendums are not distributed evenly across all member-states - Ireland and Denmark together account for ten of the 19 referendums, and the cases are unevenly distributed between countries because the EU grew from 12 to 27 member-states during the period. ${ }^{6}$ Additionally, because each country is observed at different time points, the data breaks the assumption of independence of observation. To avoid biasing the results due to these problems clustered robust standard errors are used (Rogers, 1993; Williams, 2000), which allow for the breaking of the independence and homoskedasticity assumptions.

Finally, the small sample size raises the additional concern of overfitting. Ideally of course the sample size would be larger. However it is not just an issue of practicality but of impossibility -the dataset already covers all of the existing relevant cases of EU treaty ratification. In order to guard against problems caused by the small sample size statistical models will be built cautiously, following

\footnotetext{
${ }^{6}$ A sceptical reader might wonder whether the results are entirely driven by the fact that Denmark and Ireland account for almost half of the referendum cases. The results presented here are robust to the exclusion of Denmark and Ireland as shown in table A2 in the appendix.
} 
the advice of Hosmer and Lemeshow (2000) by building models incrementally to ensure that the results are not simply due to overfitting a relatively large number of variables to a small data set.

\section{Results and Discussion}

The results of the model building process are shown in table $A 2$ in the appendix. First the electoral pressure and institutional pressure portions of the model are constructed separately before being combined, which shows that the effects of each part of the model are robust to the exclusion of the other, suggesting that the results are not simply due to overfitting. Only one of the hypothesised effects - minority government - is not statistically significant at either stage of the analysis. Hosmer and Lemeshow (2000) suggest excluding statistically insignificant variables as an additional caution against overfitting and so the institutional only and full models are re-run excluding the minority variable. In both cases the coefficients of the other variables remain stable whilst the fit statistics measured by the Bayesian Information Criterion (BIC) and Akaike information criterion (AIC) indicate that the minority variable decreases model fit, suggesting that is simply adding error to the model. Consequently the final model used in the analysis is the full model excluding the minority variable. The full models, including and excluding minority are shown in table 2.

The results of these models give strong support for the theory that domestic pressure drives the decision to hold a referendum on an EU treaty. As was hypothesised, there is a statistically significant interaction between public support for European integration and the time until the next election. Figure 1 illustrates this interaction and shows that the probability of a referendum being held increases when public support for European integration is low (hypothesis 1a) and elections are close (hypothesis $1 \mathrm{~b}$ ) and that the interaction between the two is important - referendums are likely to be held when both of these factors hold (hypothesis 1c). It also shows that the opposite case is 
true and referendums are predicted when public support for European integration is high and elections are far away. Most of the graph is flat, illustrating that for most levels of public support and time until elections, and without accounting for additional pressure from any treaty effects, the probability of a referendum being held is very low, which fits with the reality that referendums are rare events and governments prefer to take the safer parliamentary ratification route.

\begin{tabular}{|c|c|c|}
\hline & \multicolumn{2}{|c|}{ Model } \\
\hline & 1 & 2 \\
\hline \multirow{2}{*}{ Public Support } & $-0.0784 * *$ & $-0.0775 * * *$ \\
\hline & $(0.0307)$ & $(0.0286)$ \\
\hline \multirow{2}{*}{ Days till Election } & $-0.0111 * * *$ & $-0.0109 * *$ \\
\hline & $(0.0040)$ & $(0.0037)$ \\
\hline Public Support X Days till & $0.0002 * * *$ & $0.0002 * * *$ \\
\hline election & $(0.0002)$ & $(0.0001)$ \\
\hline \multirow{2}{*}{ Compulsory Referendum } & $4.8382 * * *$ & $4.9483 * * *$ \\
\hline & $(0.8165)$ & $(0.7763)$ \\
\hline \multirow{2}{*}{ Bicameral } & $1.7034^{* *}$ & $1.6431^{* * *}$ \\
\hline & $(0.8313)$ & $(0.6416)$ \\
\hline \multirow{2}{*}{ Semi-presidential } & $1.5172^{* *}$ & $1.4833^{* *}$ \\
\hline & $(0.7199)$ & $(0.6835)$ \\
\hline \multirow{2}{*}{ Minority } & 0.2310 & \\
\hline & $(1.2558)$ & \\
\hline \multirow{2}{*}{ Constant } & 1.0395 & 1.0645 \\
\hline & $(1.5251)$ & $(1.5167)$ \\
\hline$n$ & 106 & 106 \\
\hline$A / C$ & 72.57447 & 70.60862 \\
\hline$B I C$ & 93.88198 & 89.2527 \\
\hline ROC C & 0.9183 & 0.9171 \\
\hline Parliament Correct & $96.55 \%$ & $96.55 \%$ \\
\hline Referendum Correct & $47.37 \%$ & $47.37 \%$ \\
\hline
\end{tabular}

Table 2: Logistic regression models estimating the effects of domestic political factors on the probability of a referendum being held on an EU treaty. 


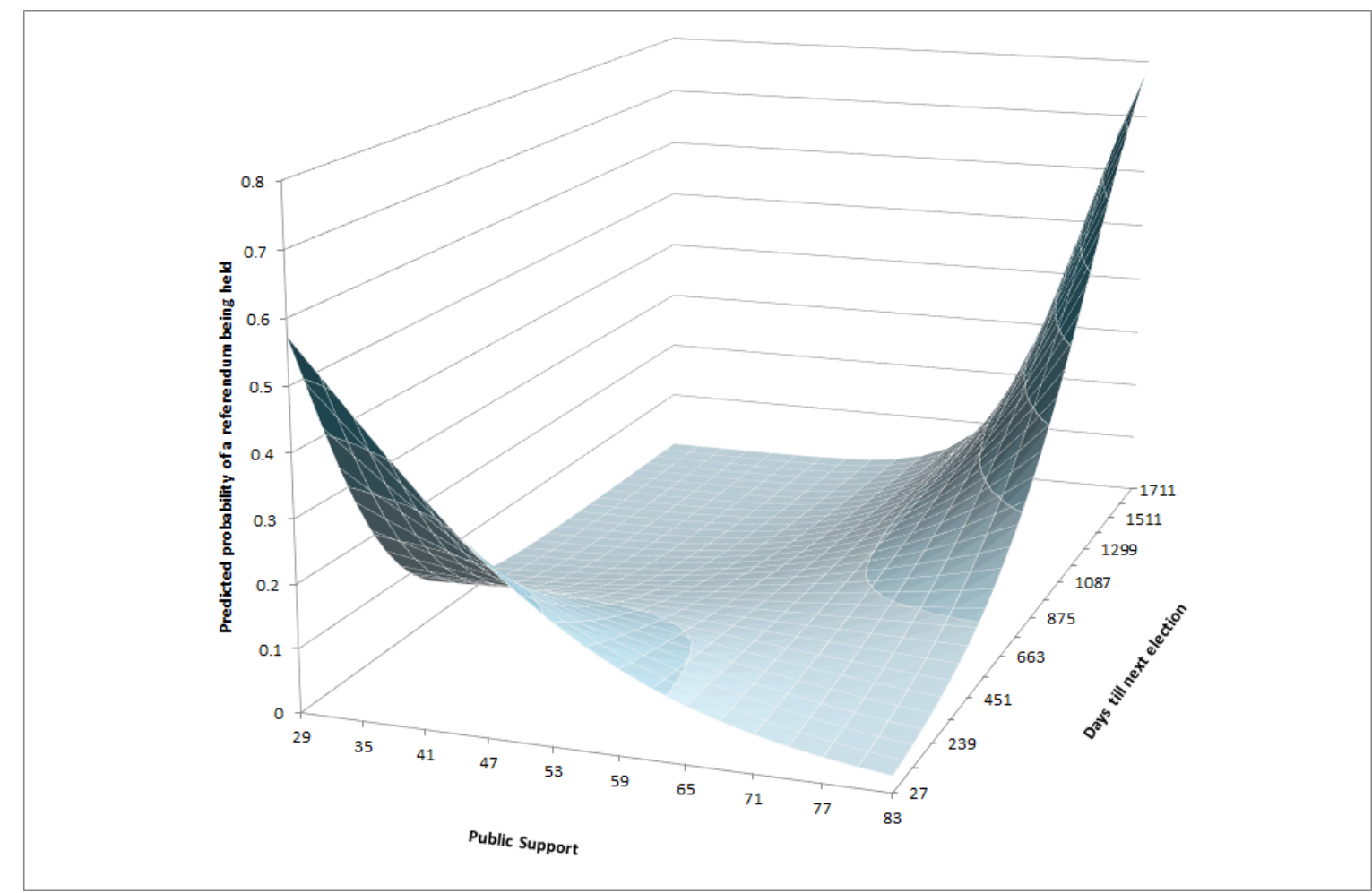

Figure 1: The effect of Public Support and Days till Election on the predicted probability of a referendum being held. All other variables are held at their median values (Compulsory Referendum = 0 , Bicameral = 1, Semi-presidential $=0$ ).

The first of these findings fits with the theory that governments hold referendums when they face the risk of electoral punishment over European integration. The second finding, that referendums are also likely when European integration is popular and elections are far away, is less expected from the perspective of this theory, but it suggests that the model is also picking up an alternative domestic drive for a referendum, similar to Oppermann's (2013a) domestic-offensive type. Ratifying a treaty through a referendum may have benefits for governments in terms of popularity and approval. However, the results here suggest that governments are risk-averse and will only call referendums when they are sure that a referendum will pass (high public support) and when they have a time buffer in case things do not go to plan (elections are far away).

As expected, compulsory referendum is statistically significant, indicating that some form of legal obligation to hold a referendum significantly increases the probability of a referendum being held (hypothesis 2). If figure 1 was redrawn with compulsory referendum held at one the results would 
be almost the opposite: for the most part, the probability of a referendum being held is very high. When European integration is unpopular and elections are sufficiently far away the probability of a referendum being held drops considerably. The only time a referendum is not predicted to be held when elections are close is when public support for integration is very high. This supports the theory outlined earlier that legal obligations to hold a referendum increase the political pressure to hold a referendum rather than simply create a legal obligation to hold one.

Both bicameral (hypothesis 3a) and semi-presidential (hypothesis 3b) are statistically significant and indicate that the presence of each veto players increases the probability of a referendum being held, with bicamerialism having a larger effect. However, no support is found for the effect of minority (hypothesis 3c). Given its prominence in the literature on both European integration referendums and referendums more broadly this is a surprising result. It suggests that although European integration is a difficult issue for governments, it is not a difficult issue for specifically minority governments and their general ability to command the confidence of parliament extends to European issues. The focus on minority governments perhaps stems from the Danish case, which has had a minority government during all of the previous EU treaties. The comparative perspective taken here suggests that the importance of minority government on the decision to hold a referendum may have been exaggerated.

Figure 2 illustrates the effect of the different veto players in terms of the change in the predicted probability (marginal effect) of a referendum being held between a case with and without a veto player across different levels of public support and time until the next election. As was expected, the impact of the veto players is not an absolute increase in the probability of a referendum being held but one that is contingent on electoral pressure - as support for European integration grows and the time until the next election increases the impact of veto players diminishes. This suggests that the bargaining power of veto players is contingent on public attitudes to European integration and the timing of elections. As figure 2 illustrates, both veto players have a similar magnitude of effect, 
though there is greater statistical uncertainty about the effect of semi-presidentialism. The average (marginal) effect of a case having a bicameral parliament is an $11 \%$ increase in the probability of a referendum being held $(p=0.007)$ whilst having a semi-presidential system increases the probability of a referendum by $13 \%(p=0.035)$.

These results suggests that, leaving the effect of public support and electoral timing to one side, some EU member-states are systematically more likely to hold referendums on EU treaties than others. With compulsory referendums and a bicameral parliament, Ireland tops this list, closely followed by Denmark, with compulsory referendums and a unicameral parliament. The next most likely are Austria, France, Poland, and Romania which have both bicameral parliaments and a semipresidential system of government. These are followed by the eight bicameral parliamentary member-states - Belgium, the Czech Republic, Germany, Italy, the Netherlands, Slovenia, Spain, and the UK, and the four unicameral semi-presidential member-states - Bulgaria, Lithuania, Portugal, and Slovakia. Together these member-states account for all but one of the referendums held on EU treaties (the remaining referendum being the Luxembourg referendum on the Constitutional Treaty).

Only six of the countries that have the institutional configuration that make referendums more likely - Austria, Bulgaria, Italy, Lithuania, Slovakia, and Romania - have not held any treaty referendums. With Bulgaria, Lithuania, Slovakia and Romania all being relative new comers to the EU, the two most interesting cases are Austria and Italy, which are both illustrative of different aspects of the effect of electoral pressure to hold a referendum. 

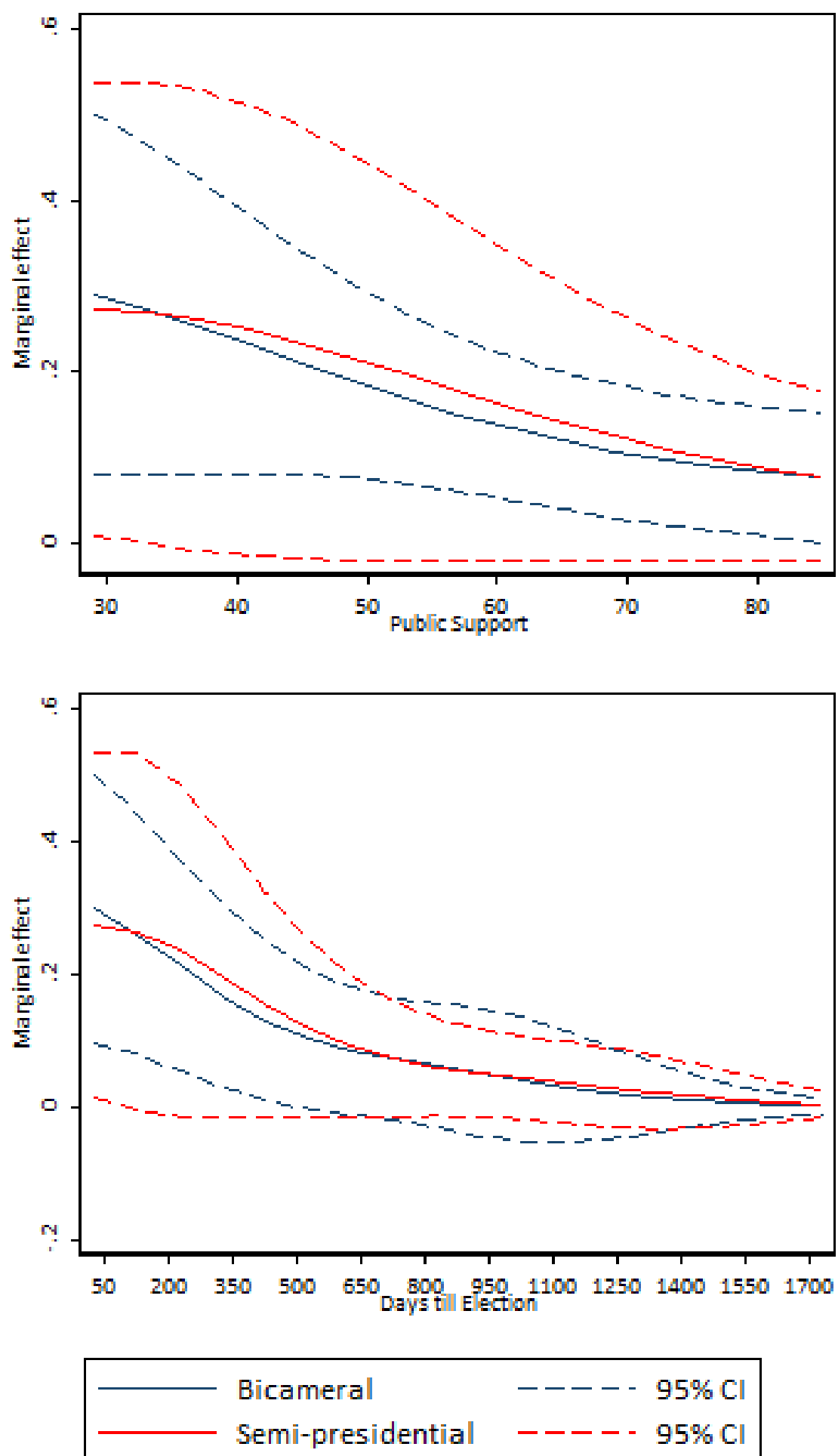

Figure 2: The effect of Bicameral and Semi-Presidential illustrated by the marginal effect (change in predicted probability) of each variable at changing values of Public Support (with Days till Election held at 120) and Days till Election (with Public Support held at 35) on the probability of a referendum being held. 
Looking purely at public support for European integration, electoral pressure to hold a referendum in Austria appears to be very high, with a public support mean of 37.25 . Indeed political discourse over the EU in Austria often revolves around calls for a referendum on the EU. Looking at the timing of Austrian elections relative to EU treaties helps provide an explanation of why Austrian governments have been able to avoid holding referendums. Austria has a relatively long mean time ( 589.75 days) between the signing of a treaty and elections. Furthermore, in the only case where the election was closer than this mean time - the Lisbon Treaty - this was an unexpected election caused by the collapse of the governing coalition. At the time the treaty was signed the election was not due for an additional three years.

Italy represents almost the polar opposite case. Italy's mean time until an election following a treaty signing is 430.67 days but one election was held very close to treaty signing - the 1992 Italian election was held only 58 days after the the signing of the Maastricht treaty. However support for European integration in Italy is relatively high with a mean public support of 64.17, with higher support around the time of Maastricht with at 74 .

Moving on to the second stage of the analysis, the inclusion of treaty effects does not affect the overall validity of the results presented so far. Including treaty fixed effects (shown in table A3 of the appendix) does not alter the direction or statistical significance of any of the relationships between electoral pressure and institutional variables. Similarly the results are robust to specifying the model as a multilevel model with random effects at the treaty level (also shown in table A3). The convergence between these results and those presented earlier offers good evidence for the robustness of the earlier results to different specification.

It is also clear from these results that there are distinct treaty level effects which influence the probability of a referendum occurring and that the pattern of referendums on EU treaties cannot be explained by domestic factors alone. Using the likelihood-ratio tests on the multilevel specification of the model alternatively specified as random intercept and random coefficient models suggest that 
treaty level effects are best modelled by a random intercept approach. This suggests that the effect of different treaties is an increase or decrease in the political pressure to hold a referendum, operating in much the same way as the institutional variables. Estimates of the magnitude of each treaty effect taken from the fixed and multilevel models are shown in table 3. Both specifications suggests that there have been distinct treaty effects for the three most recent treaties: the Nice, Constitutional, and Lisbon treaties.

For the Nice and Lisbon treaties this effect manifests itself as a decrease in the probability of referendums (by about 15\% and 19\% respectively using estimates from the fixed effects models) from what we would otherwise expect. A finding which supports Oppermann's (2013b) argument that member-states actively sought to avoid referendums on the Lisbon Treaty. The effect of the Constitutional treaty is an increase in the probability of referendums being held (by about $31 \%$ according to the fixed effects model) from what we would otherwise expect, suggesting either that the significance of the Constitutional Treaty increased pressure on governments to hold referendums, or, as Closa (2007) suggests, that the decision to hold referendums in some states increased the pressure to hold them in others. The multilevel model results also suggest that the Maastricht Treaty had a similar, albeit smaller, effect to the Constitutional treaty, though these results are not supported by the fixed effects model so the robustness of this result is unclear.

\begin{tabular}{ccccccc}
\hline Treaty & SEA & Maastricht & Amsterdam & Nice & Constitution & Lisbon \\
\hline BLUP & 0.3333 & 3.1325 & -0.0075 & -4.675 & 5.8585 & -3.8929 \\
Standard Error & $(1.9095)$ & $(1.2898)$ & $(3.4177)$ & $(1.5681)$ & $(0.6338)$ & $(1.9365)$ \\
\hline Fixed effect & & & & - & & - \\
coefficient & -0.6116 & 0.7583 & -0.8569 & $3.6236 * * *$ & $4.6855^{* * *}$ & $5.8163^{* * *}$ \\
Standard Error & $(0.8456)$ & $(0.7284)$ & $(0.7337)$ & $(0.7912)$ & $(0.9269)$ & $(1.5349)$ \\
\hline Marginal effect & -0.0429 & 0.066 & -0.0573 & -0.1492 & 0.3097 & -0.1908 \\
\hline
\end{tabular}

Statistical Significance (only applicable to fixed effects coefficients): $* * *=p<0.01$.

Table 3: Best Linear Unbiased Predictions (BLUPS), fixed effect coefficients, and marginal effects (average change in predicted probability, estimated from fixed effects) showing the effect of individual treaties on the probability of a referendum being held. 
Exactly how important these treaty effects are depends on the question of interest. From a purely statistical perspective the treaty effects explain most of the variation in the data (the Intraclass Correlation coefficient for the treaty level in the multilevel model is 0.8331 ), suggesting that treaty differences explain most of why more referendums have been held on some treaties than others, and it is not that the alignment of public opinion and electoral timing happened to coincide on certain treaties. However, treaty differences do not explain why some member-states hold referendums whilst others do not. Predicting outcomes using only the treaty portion of the model predicts that all member-states would have held referendums on the SEA, Maastricht, Amsterdam, and Constitutional treaties and no member-states would have held referendums on the Nice and Lisbon treaties, which gets 17 of the 19 referendum cases correct but only 40 of the 87 parliamentary cases correct, yielding a ROC C (area under the curve) statistic of 0.7505 . Conversely, ignoring the treaty level effects and generating predictions from the domestic politics model (i.e. model 2 in table 2) still correctly predicts 85 of the 87 parliamentary cases correctly and nine of 19 referendum cases correctly, with a ROC C statistic of 0.9171 , indicating better overall fit for the domestic only portion of the model.

Obviously separating the components of the model is an artificial exercise and the role that domestic political factors play must be seen within the context of each EU treaty. The best predictive capability is given by the multilevel specification of the full model, which yields remarkably accurate predictions of the pattern of EU treaty referendums. The full multilevel model correctly predicts 101 of the 106 cases: 85 of the 87 parliamentary cases, and 16 of the 19 referendum cases, and yields a ROC C statistic of 0.9909 , indicating excellent model fit. The cases the model predicts incorrectly are themselves illustrative of its strength. All five incorrectly classified cases are on the Constitutional treaty: the model incorrectly predicts that Austria and Belgium should have held referendums, and that the Czech Republic, the Netherlands, and Portugal should not. As an outcome is predicted when the probability of a referendum being held is greater than 0.5 , assessing whether or not a result is 'wrong' is a difficult task. Predictions must be assessed by more relative means - how improbable 
are the 'incorrect' predictions? In three of the cases the ratification route that a member state took is not implausible given the predicted probability - Belgium is predicted a 0.53 chance of a referendum, the Netherlands 0.49 , and Portugal 0.44 . In these three cases the probability of the actual ratification route taken ranges from 46 per cent to 49 per cent, by no means completely unlikely events.

The other two cases are more interesting. The model predicts that the Czech Republic only had a 0.20 probability of holding a referendum on the Constitutional Treaty. The events surrounding the Czech referendum are illustrative of the effects that a presidential figure may have in the decision to hold a referendum. Although the Czech Republic is classified as a parliamentary system in this analysis and the constitutional powers of the President of the Czech Republic are quite limited, through the personal popularity of some of the holders of the office some Presidents are able to wield considerable political power. At the time of the Constitutional Treaty President Václav Klaus voiced considerable opposition to the treaty and became a rallying point for Czech eurosceptics. If the Czech Republic is classified as a Semi-Presidential system instead, the predicted probability of a referendum on the Constitutional treaty would increase to 0.89 , which is perhaps a more accurate reflection of what actually happened.

Conversely, Austria is predicted a 0.76 probability of holding a referendum on the Constitutional treaty (although even here there is an almost one in four chance of a referendum not being held). What might explain the fact that Austria didn't hold a referendum? One possibility is that by Austrian standards, public support for European integration was relatively high at the time of the Constitutional Treaty (public support is at least eight points higher at the Constitutional Treaty compared to any other treaty). Another plausible explanation is the reverse of the Czech case. Although the Austrian President has considerable power on paper, in practice it is rarely exercised. If Austria is coded as though it were a parliamentary system the predicted probability of a referendum decreases to 0.08 . 


\section{Conclusion}

The analysis here provides clear evidence that the pattern of referendums on EU treaties is explained by a combination of domestic level political factors - electoral pressure over European integration, legal obligations to hold referendums, and domestic institutional veto players - and differences between EU treaties. The remarkable accuracy of the model in predicting the ratification pattern of EU treaties without reference to factors relating to treaty negotiation strategy echoes Oppermann's (2013a) argument that undue weight has been given to European level explanations and insufficient attention has been paid to the role that domestic factors play in the decision to call a referendum. That this is the case perhaps helps explain why many EU referendums have failed: they are often held precisely because of the circumstances that make it difficult to rally support in favour of European integration.

These findings fit well with a growing empirical consensus that referendums on the Constitutional Treaty were held because of electoral pressure. By extending the analysis beyond a single treaty this article has shown that a generalisable pattern of calling EU referendums exists, albeit with important differences in the political pressure that different treaties bring to bear on the ratification process.

That a member-state's institutional structure, particularly whether it is bicameral or semipresidential, influences the probability of a referendum being held is a new contribution to the literature on referendums on European integration. The role of domestic political institutions has also been neglected in the wider literature on European integration, and the findings here point to the importance of understanding domestic political structures in the domestic politics of European integration, and that future research is necessary to understand their influence.

The results here suggest a number of avenues for future research. Although it is clear that different treaties produce differing degrees of political pressure for referendums, it is not necessarily obvious why this is the case. Do elites and citizens respond to specific developments in treaties or does 
electoral pressure stem from more general attitudes towards the EU? How do (promised) referendums on earlier treaties or those held in other member-states affect the pressure to hold a referendum? Similarly, while it is clear that veto players play a key role in the decision to hold referendums, there is much to learn about the importance of constitutional and political powers in determining the role that veto players might play: Does cohabitation between executive presidents and parliaments matter? Do some upper chambers increase the pressure to hold referendums more than others, and if so, why? Similarly there are many other veto players that could potentially play a role in the pressure to hold referendums, from constitutional courts (as the Irish case suggests) to lower levels of government in federal countries. Finally, what role do other legal provisions, such as those regulating the role of referendums more generally, or the place of international law in domestic law (i.e. monism vs dualism), play in the political decision to hold referendums?

A particularly pressing concern is whether the repeated rejection of European treaties at referendums has led to an increased reluctance to hold them and what this might mean for the future of European integration. If member-states are more reluctant to hold referendums because of past failures, they could become a thing of the past. However, at least two member-states, Austria and the UK, have already promised future referendums: the Austrian government announced in 2008 that it would hold a referendum on Turkish membership of the EU if accession talks concluded in favour of a membership agreement, and the British government passed the European Union Act 2011 requiring a referendum on any future EU treaties. However the likelihood of referendums being held on future treaties and the high risk that the electorate in some countries might reject a new treaty, delaying or blocking reform, seems to have led to an increased reluctance on the part of EU member-states to actually engage in major treaty negotiations, a development which will have a serious impact on the future direction of European integration. Whether or not they are actually held, referendums look likely to continue to play an important and turbulent role in European integration. 


\section{References}

Bjørklund, T. (1982) 'The Demand for Referendum: When Does It Arise and When Does It Succeed?', Scandinavian Political Studies, 5(3), 237-59.

Bowler, S., Donovan, T. and Karp, J. A. (2007) 'Enraged or Engaged? Preferences for Direct Citizen Participation in Affluent Democracies', Political Research Quarterly, 60(3), 351-62.

Butler, D. and Ranney, A. (eds.) (1978) Referendums: A comparative Study of Practice and Theory. Washington D.C.: American Enterprise for Public Policy Research.

Butler, D. and Ranney, A. (eds.) (1994) Referendums around the World: The Growing use of direct democracy. London: Macmillan.

Closa, C. (2007) 'Why Convene Referendums? Explaining Choices in EU Constitutional Politics', Journal of European Public Policy, 14(8), 1311-32.

Dür, A. and Mateo, G. (2011) 'To Call or Not to Call? Political Parties and Referendums on the EU's Constitutional Treaty.', Comparative Political Studies, 44(4), 468-92.

Elster, J. (ed.) (1998) Deliberative Democracy. Cambridge: Cambridge University Press.

Finke, D. and König, T. (2009) 'Why risk popular ratification failure? A comparative analysis of the choice of the ratification instrument in the 25 Member States of the EU', Constitutional Political Economy, 20, 341-65.

Franklin, M., Marsh, M. and McLaren, L. (1994) 'Uncorking the Bottle: Popular Opposition to European Unification in the Wake of Maastricht', Journal of Common Market Studies, 32(4), $455-72$.

Garry, J., Marsh, M. and Sinnott, R. (2005) "Second-order" versus "Issue-voting" Effects in EU Referendums', European Union Politics, 6(2), 201-21.

Glencross, A. and Trechsel, A. (2011) 'First or Second Order Referendums? Understanding the Votes on the EU Constitutional Treaty in Four EU Member States', West European Politics, 34(4), $755-72$. 
Hibbing, J. R. and Theiss-Morse, E. (2002) Stealth Democracy: Americans' Beliefs About How Government Should Work. Cambridge University Press.

Hobolt, S. (2005) 'When Europe Matters: The Impact of Political Information on Voting Behaviour in EU Referendums', Journal of Elections, Public Opinion \& Parties, 15(1), 85-110.

Hobolt, S. (2006a) 'How Parties Affect Vote Choice in European Integration Referendums', Party Politics, 12(5), 623-47.

Hobolt, S. (2006b) 'Direct Democracy and European Integration', Journal of European Public Policy, 13(1), 153-66.

Hobolt, S. (2007) 'Taking Cues on Europe? Voter Competence and Party Endorsements in Referendums on European Integration', European Journal of Political Research, 46(2), 15182.

Hobolt, S., Spoon, J.-J. and Tilley, J. R. (2009) 'A Vote against Europe? Explaining Defection at the 1999 and 2004 European Parliament Elections', British Journal of Political Science, 39(1), 123.

Hosmer, D. W. and Lemeshow, S. (2000) Applied Logistic Regression, Second Edition. New York: John Wiley \& Sons.

Hug, S. and König, T. (2002) 'In view of Ratification: Governmental Preferences and Domestic Constraints at the Amsterdam Intergovernmental Conference', International Organization, $56(2), 447-76$.

Laursen, F. (2010) 'Denmark and the Ratification of the Lisbon Treaty: How a Referendum was avoided', Presented at the 4th Annual EUCE conference, Dalhousie University, 6 June.

LeDuc, L. (2003) The Politics of Direct Democracy: Referendums in Global Perspective. Toronto: University of Toronto Press.

Mackie, T. T. and Rose, R. (1990) The International Almanac of Electoral History, Third Edition. Houndmills, Basingstoke, Hampshire: Palgrave MacMillan. 
Mateo, G. (2006) Domestic Politics and Referendums on the Constitutional Treaty. Robert Schuman Centre for Advanced Studies: European University Institute.

Morel, L. (2001) 'The Rise of Government-initiated Referendums in Consolidated Democracies', in M. Mendelsohn and A. Parkin (eds.), Referendum Democracy: Citizens, Elites and Deliberation. New York: Palgrave, pp. 47-64.

Oppermann, K. (2013a) 'The politics of discretionary government commitments to European integration referendums', Journal of European Public Policy, 20(5), 684-701.

Oppermann, K. (2013b) 'The politics of avoiding referendums on the Treaty of Lisbon', Journal of European Integration, 35(1), 73-89.

Qvortrup, M. (2005) A Comparative Study of Referendums: Government by the People, Second Edition. Manchester: Manchester University Press.

Qvortrup, M. (2014) Referendums and Ethnic Conflict. Philadelphia: University of Pennsylvania Press.

Rogers, W. H. (1993) 'Regression standard errors in clustered samples', Stata Technical Bulletin, 13, $19-23$.

Schneider, G. and Cederman, L.-E. (1994) 'The Change of Tide in Political Cooperation: A Limited Information Model of European Integration', International Organization, 48(4), 633=662.

Shugart, M. S. (2006) 'Comparative Executive-Legislative Relations', in R. A. W. Rhodes, Sarah A. Binder and Bert A. Rockman (eds.), The Oxford Handbook of Political Institutions. Oxford and New York: Oxford University Press, pp. 344-65.

Stegmueller, D. (2013) 'How Many Countries for Multilevel Modeling? A Comparison of Frequentist and Bayesian Approaches', American Journal of Political Science, 57(3), 748-61.

Tsebelis, G. (2002) Veto Players: How Political Institutions Work. New York and Princeton, New Jersey: Russell Sage Foundation and Princeton University Press.

Uleri, P. V. (2002) ‘On referendum Voting in Italy: Yes, No or Non-vote? How Italian Parties Learned to Control Referenda', European Journal of Political Research, 41, 863-83. 
Williams, R. L. (2000) 'A note on robust variance estimation for cluster-correlated data', Biometrics, $56,645-6$.

Woldendorp, J., Keman, H. and Budge, I. (2000) Party Government in 48 Democracies (1945-1998): Composition - Duration - Personnel. Dordrecht, Boston and London: Kluwer Academic Publishers. 


\section{Appendix}

\begin{tabular}{|c|c|c|c|c|}
\hline Variable & Mean & $\begin{array}{l}\text { Standard } \\
\text { Deviation }\end{array}$ & Minimum & Maximum \\
\hline Public Support & 56.53 & 13.74 & 29 & 85 \\
\hline Days till Election & 715.76 & 423.95 & 27 & 1711 \\
\hline
\end{tabular}

$\%$ of cases

Countries coded 1

$\begin{array}{cc}\begin{array}{c}\text { Compulsory } \\ \text { Referendum }\end{array} & 11.32 \\ \text { Bicameral } & 55.66 \\ \text { Semi- } & \\ \text { presidential } & 22.64\end{array}$

Denmark, Ireland

Austria, Belgium, Czech Republic, France, Germany, Ireland, Italy, Netherlands, Poland, Romania, Slovenia, Spain, UK

Austria, Bulgaria, France, Lithuania, Poland, Portugal, Romania, Slovakia

SEA: Denmark, Greece, Netherlands, Portugal.

Maastricht: Denmark, Netherlands,

Minority

18.87

Amsterdam: Denmark, Ireland, Luxembourg, Portugal, Sweden.

Nice: Denmark, Sweden.

Constitution: Denmark, Lativa, Slovenia, Spain, Sweden.

Lisbon: Denmark, Spain.

Table A1: Summary statistics and binary variable coding. 


\begin{tabular}{|c|c|c|c|c|c|c|c|c|c|c|c|c|c|}
\hline & \multicolumn{4}{|c|}{ Electoral pressure only models } & \multicolumn{6}{|c|}{ Institutional pressure only models } & \multicolumn{2}{|c|}{ Combined models } & \multirow{2}{*}{$\begin{array}{c}\text { Excluding } \\
\text { Denmark and } \\
\text { Ireland }\end{array}$} \\
\hline & 1 & 2 & 3 & 4 & 1 & 2 & 3 & 4 & 5 & 6 & 1 & 2 & \\
\hline Public Support & .0310 & & 0.0331 & $0.0589^{* * *}$ & & & & & & & $-0.0784^{* *}$ & $\stackrel{-}{-} .0775^{* * *}$ & $-0.0931^{* * *}$ \\
\hline & $(0.0259)$ & & $(0.0258)$ & $(0.0218)$ & & & & & & & $(0.0307)$ & $(0.0286)$ & $(0.0249)$ \\
\hline Days till Election & & $\begin{array}{l}-0.0002 \\
(0.0006)\end{array}$ & $\begin{array}{l}-0.0004 \\
(0.0005)\end{array}$ & $\begin{array}{c}- \\
0.0099^{* * *} \\
(0.0025)\end{array}$ & & & & & & & $\begin{array}{c}- \\
0.0111^{* * *} \\
(0.0040)\end{array}$ & $\begin{array}{c}-0.0109 * * \\
(0.0037)\end{array}$ & $\begin{array}{c}-0.0136^{* * *} \\
(0.0035)\end{array}$ \\
\hline $\begin{array}{l}\text { Public Support X Days till } \\
\text { election }\end{array}$ & & & & $\begin{array}{c}0.0001^{* * *} \\
(0.00003)\end{array}$ & & & & & & & $\begin{array}{c}0.0002^{* * *} \\
(0.0002)\end{array}$ & $\begin{array}{c}0.0002^{* * *} \\
(0.0001)\end{array}$ & $\begin{array}{c}0.0002^{* * *} \\
(0.00005)\end{array}$ \\
\hline Compulsory Referendum & & & & & $\begin{array}{c}3.8549 * * * \\
(0.9202)\end{array}$ & & & & $\begin{array}{c}4.7967^{* * *} \\
(0.9418)\end{array}$ & $\begin{array}{c}4.6660^{* * *} \\
(0.7536)\end{array}$ & $\begin{array}{c}4.8382^{* * *} \\
(0.8165)\end{array}$ & $\begin{array}{c}4.9483^{* * *} \\
(0.7763)\end{array}$ & \\
\hline Bicameral & & & & & & $\begin{array}{c}0.6581 \\
(0.8713)\end{array}$ & & & $\begin{array}{l}1.4149 * \\
(0.8311)\end{array}$ & $\begin{array}{c}1.4778^{* *} \\
(0.6917)\end{array}$ & $\begin{array}{c}1.7034^{* *} \\
(0.8313)\end{array}$ & $\begin{array}{c}1.6431^{* * *} \\
(0.6416)\end{array}$ & $\begin{array}{c}1.6466^{* *} \\
(0.7546)\end{array}$ \\
\hline Semi-presidential & & & & & & & $\begin{array}{l}-0.1128 \\
(0.6901)\end{array}$ & & $\begin{array}{l}1.0060 \\
(0.6194)\end{array}$ & $\begin{array}{l}1.0316^{*} \\
(0.6047)\end{array}$ & $\begin{array}{c}1.5172^{* *} \\
(0.7199)\end{array}$ & $\begin{array}{c}1.4833^{* *} \\
(0.6835)\end{array}$ & $\begin{array}{c}1.6744^{* *} \\
(0.7413)\end{array}$ \\
\hline Minority & & & & & & & & $\begin{array}{c}0.8782 \\
(0.7298)\end{array}$ & $\begin{array}{l}-0.2501 \\
(1.3083)\end{array}$ & & $\begin{array}{c}0.2310 \\
(1.2558)\end{array}$ & & \\
\hline Constant & $\begin{array}{c}- \\
3.6870 * * \\
(1.5320)\end{array}$ & $\begin{array}{c}- \\
1.348 * * \\
(0.5901)\end{array}$ & $\begin{array}{c}- \\
3.5484 * \\
(1.6783)\end{array}$ & $\begin{array}{c}2.6115^{* * *} \\
(1.1591)\end{array}$ & $\begin{array}{c}- \\
2.2454^{* * *} \\
(0.3147)\end{array}$ & $\begin{array}{c}- \\
1.9218^{* * *} \\
(0.6786)\end{array}$ & $\begin{array}{c}- \\
1.4966^{* * *} \\
(0.5232)\end{array}$ & $\begin{array}{c}- \\
1.7255^{* * *} \\
(0.4651)\end{array}$ & $\begin{array}{c}- \\
3.5440 * * * \\
(0.9277)\end{array}$ & $\begin{array}{c}- \\
3.6167^{* * *} \\
(0.7418)\end{array}$ & $\begin{array}{l}1.0395 \\
(1.5251)\end{array}$ & $\begin{array}{l}1.0645 \\
(1.5167)\end{array}$ & $\begin{array}{c}1.8557 \\
(1.4503)\end{array}$ \\
\hline $\begin{array}{l}\text { Treaty random intercept } \\
\text { (Standard Deviation) }\end{array}$ & & & & & & & & & & & & & \\
\hline$n$ & 106 & 106 & 106 & 106 & 106 & 106 & 106 & 106 & 106 & 106 & 106 & 106 & 94 \\
\hline$A I C$ & 101.0026 & 103.526 & 102.576 & 95.3907 & 74.15213 & 102.1256 & 103.6586 & 101.4865 & 74.3548 & 72.4023 & 72.57447 & 70.60862 & 57.04929 \\
\hline$B I C$ & 106.3295 & 108.853 & 110.566 & 106.0445 & 79.47901 & 107.4525 & 108.9855 & 106.8134 & 87.67199 & 83.0561 & 93.88198 & 89.2527 & 72.30906 \\
\hline $\mathrm{ROCC}$ & 0.6044 & 0.543 & 0.6419 & 0.7302 & 0.9398 & 0.5777 & 0.5097 & 0.5774 & 0.8327 & 0.8364 & 0.9183 & 0.9171 & 0.8549 \\
\hline Parliament Correct & $100 \%$ & $100 \%$ & $100 \%$ & $99 \%$ & $97.70 \%$ & $100 \%$ & $100 \%$ & $100 \%$ & $97.70 \%$ & $97.70 \%$ & $96.55 \%$ & $96.55 \%$ & $96.47 \%$ \\
\hline Referendum Correct & $0 \%$ & $0 \%$ & $0 \%$ & $10.53 \%$ & $52.63 \%$ & $0 \%$ & $0 \%$ & $0 \%$ & $52.63 \%$ & $52.63 \%$ & $47.37 \%$ & $47.37 \%$ & $11.11 \%$ \\
\hline
\end{tabular}

Table A2: The model building process: logistic regression models showing the electoral pressure only, institutional pressure only, and combined model. The table also shows the final full model run excluding the Danish and Irish cases as a robustness check. 


\begin{tabular}{|c|c|c|c|c|c|c|c|}
\hline & SEA & Maatricht & Amsterdam & Nice & Constitution & Lisbon & $\begin{array}{l}\text { Multilevel model } \\
\text { with treaty effects }\end{array}$ \\
\hline Public Support & $\begin{array}{c}-0.0751^{* * *} \\
(0.028)\end{array}$ & $\begin{array}{c}-0.0856 * * * \\
(0.0285)\end{array}$ & $\begin{array}{c}-0.0782 * * * \\
(0.0294)\end{array}$ & $\begin{array}{c}-0.1134 * * * \\
(0.0422)\end{array}$ & $\begin{array}{c}-0.0941 * * \\
(0.0438)\end{array}$ & $\begin{array}{c}-0.0902 * * * \\
(0.0271)\end{array}$ & $\begin{array}{l}-0.1961 \\
(0.1247)\end{array}$ \\
\hline Days till Election & $\begin{array}{c}-0.0108 * * * \\
(0.0037)\end{array}$ & $\begin{array}{c}-0.0118^{* * *} \\
(0.0035)\end{array}$ & $\begin{array}{c}-0.0107^{* * *} \\
(0.0035)\end{array}$ & $\begin{array}{c}-0.0144 * * * \\
(0.0041)\end{array}$ & $\begin{array}{c}-0.0128 * * \\
(0.0053)\end{array}$ & $\begin{array}{c}-0.0142 * * * \\
(0.0042)\end{array}$ & $\begin{array}{c}-0.0264 * * \\
(0.0134)\end{array}$ \\
\hline $\begin{array}{l}\text { Public Support X } \\
\text { Days till election }\end{array}$ & $\begin{array}{c}0.0002 * * * \\
(0.0001)\end{array}$ & $\begin{array}{c}0.0002^{* * *} \\
(0.0001)\end{array}$ & $\begin{array}{c}0.0002 * * * \\
(0.0001)\end{array}$ & $\begin{array}{c}0.0002 * * * \\
(0.0001)\end{array}$ & $\begin{array}{c}0.0002 * * \\
(0.0001)\end{array}$ & $\begin{array}{c}0.0002 * * * \\
(0.0001)\end{array}$ & $\begin{array}{c}0.0004 * * \\
(0.0002)\end{array}$ \\
\hline $\begin{array}{l}\text { Compulsory } \\
\text { Referendum }\end{array}$ & $\begin{array}{c}5.0048 * * * \\
(0.8516)\end{array}$ & $\begin{array}{c}4.9322^{* * *} \\
(0.7645)\end{array}$ & $\begin{array}{c}4.9418^{* * *} \\
(0.7814)\end{array}$ & $\begin{array}{c}6.1615^{* * *} \\
(0.9933)\end{array}$ & $\begin{array}{c}8.2281 * * * \\
(1.3583)\end{array}$ & $\begin{array}{c}7.358^{* * *} \\
(1.5339)\end{array}$ & $\begin{array}{c}13.4004^{* *} \\
(5.2766)\end{array}$ \\
\hline Bicameral & $\begin{array}{l}1.625^{* * *} \\
(0.6322)\end{array}$ & $\begin{array}{c}1.6376 * * * \\
(0.6396)\end{array}$ & $\begin{array}{l}1.6022^{* *} \\
(0.6441)\end{array}$ & $\begin{array}{c}2.0562 * * \\
(0.8869)\end{array}$ & $\begin{array}{c}2.7368 * * * \\
(1.042)\end{array}$ & $\begin{array}{l}2.9936 * * \\
(1.2441)\end{array}$ & $\begin{array}{c}4.4473 * * \\
(2.0802)\end{array}$ \\
\hline Semi-presidential & $\begin{array}{l}1.4553 * * \\
(0.6916)\end{array}$ & $\begin{array}{c}1.5523 * * \\
(0.6908)\end{array}$ & $\begin{array}{c}1.4169 * * \\
(0.6638)\end{array}$ & $\begin{array}{l}1.5898 * \\
(0.8323)\end{array}$ & $\begin{array}{l}2.1162 * \\
(1.2623)\end{array}$ & $\begin{array}{c}2.6365^{* * *} \\
(0.82)\end{array}$ & $\begin{array}{l}3.5282^{* *} \\
(1.7986)\end{array}$ \\
\hline Constant & $\begin{array}{c}1.059 \\
(1.5637)\end{array}$ & $\begin{array}{c}1.43280 .333 \\
(1.481)\end{array}$ & $\begin{array}{c}1.2088 \\
(1.5778)\end{array}$ & $\begin{array}{c}3.2683 \\
(2.2685)\end{array}$ & $\begin{array}{c}-1.138 \\
(1.7936)\end{array}$ & $\begin{array}{c}0.2137 \\
(1.5237)\end{array}$ & $\begin{array}{c}2.3272 \\
(6.3541)\end{array}$ \\
\hline Treaty fixed effect & $\begin{array}{l}-0.6116 \\
(0.8456)\end{array}$ & $\begin{array}{c}0.75830 .298 \\
(0.7284)\end{array}$ & $\begin{array}{l}-0.8569 \\
(0.7337)\end{array}$ & $\begin{array}{c}-3.6236 * * * \\
(0.7912)\end{array}$ & $\begin{array}{c}4.6855^{* * *} \\
(0.9269)\end{array}$ & $\begin{array}{c}-5.8163 * * * \\
(1.5349)\end{array}$ & \\
\hline $\begin{array}{l}\text { Treaty random } \\
\text { intercept (SD) }\end{array}$ & & & & & & & $\begin{array}{c}4.0535 \\
(2.0663)\end{array}$ \\
\hline$n$ & 106 & 106 & 106 & 106 & 106 & 106 & 106 \\
\hline$A I C$ & 72.31444 & 72.03231 & 72.23411 & 66.12251 & 49.89877 & 59.94218 & 52.1941 \\
\hline$B I C$ & 93.62195 & 93.33982 & 93.54162 & 87.43002 & 71.20629 & 81.24969 & 73.5016 \\
\hline ROC C & 0.9220 & 0.9111 & 0.9214 & 0.9359 & 0.9722 & 0.9456 & 0.9909 \\
\hline Parliament Correct & $97.70 \%$ & $97.70 \%$ & $97.70 \%$ & $96.55 \%$ & $94.25 \%$ & $97.70 \%$ & $97.70 \%$ \\
\hline $\begin{array}{l}\text { Referendum } \\
\text { Correct }\end{array}$ & $42.11 \%$ & $57.89 \%$ & $47.37 \%$ & $63.16 \%$ & $78.95 \%$ & $68.42 \%$ & $84.21 \%$ \\
\hline
\end{tabular}

Statistical Significance: ${ }^{*}=p<0.1,{ }^{* *}=p<0.05,{ }^{* * *}=p<0.01$.

Table A3: Models estimating the effect of treaties on the probability of a referendum being held using fixed effects and multilevel logistic regression models. 